\title{
Chiral Cyclopentadiene Ligands for the Asymmetric Allylation of Benzamides
}<smiles>[R]C=C([R])C([R])[B]</smiles>

$\mathrm{R}^{1}=\mathrm{H}, \mathrm{Me}, \mathrm{CF}_{3}, \mathrm{Cl}, \mathrm{Br}, \mathrm{OMe}$

$\mathrm{R}^{2}=\mathrm{CH}_{2} \mathrm{CH}_{2} \mathrm{OMe}, \mathrm{CH}_{2} \mathrm{CH}_{2} \mathrm{OH}, \mathrm{CH}_{2} \mathrm{OTIPS}, \mathrm{CH}_{2} \mathrm{CO}_{2} \mathrm{Et}, \mathrm{Ph}, \mathrm{Bu}$ $\mathrm{R}^{3}=\mathrm{Me}, \mathrm{Cy}$<smiles>[R]c1cccc(C(=O)NOC)c1C([R8])C=C1PCCCP1</smiles>

16 examples up to $91 \%$ yield er up to $99: 1$ $0.1 \mathrm{mmol}$ scale

Selected examples:<smiles>COCCC(C=C1CCCCC1)c1ccc(C)cc1C(=O)NOC</smiles>

$83 \%$ yield er $=96: 4$<smiles>COCCC(C=C1CCCCC1)c1cc(Br)ccc1C(=O)NOC</smiles>

$72 \%$ yield er $=97.5: 2.5$<smiles>CCOC(=O)CC(C=C(C)C)c1ccccc1C(=O)NOC</smiles>

$72 \%$ yield er $=95: 5$<smiles>CONC(=O)c1ccc(Br)cc1C(C=C(C)C)CCO</smiles>

$66 \%$ yield er $=99: 1$

Synthesis of the catalyst:<smiles>COc1cc2ccccc2c(-c2c(C)c(OC)cc3ccccc23)c1C</smiles><smiles>COc1cc2ccccc2c2c1CC1=CCC=C1Cc1c(OC)cc3ccccc3c1-2</smiles>

OMe<smiles>COc1cc2ccccc2c2c1CC1(C=CC=C1)Cc1c(OC)cc3ccccc3c1-2</smiles>

1. BuSLi, $65 \%$ yield 2. TIPS- $\mathrm{Cl}, 80 \%$ yield

\section{Key words}

cyclopentadiene

C-H allylation

rhodium(III)

benzamides

SYNFACTenth
Significance: A class of chiral Cp ligands with tuneable steric parameters is reported and used in the $\mathrm{Rh}$ (III)-catalyzed allylation of $\mathrm{N}$-methoxybenzamides. The obtained yields are good and the enantioselectivities excellent.
Comment: Cyclopentadienyl (Cp) ligands are among the most versatile and frequently used ligands to access robust and highly catalytically active transition-metal complexes. However, there are only a few chiral $\mathrm{Cp}$ ligands reported so far.

SYNFACTS Contributors: Mark Lautens, Harald Weinstabl

Synfacts 2013, 9(4), 0393 Published online: 15.03.2013

Dol: 10.1055/s-0032-1318401; Reg-No.: L02213SF 